\title{
Evaluation of the inappropriate disposal of refined soybean oil on the escape behavior of the earthworms (Eisenia fetida)
}

\author{
Heider Alves Franco ${ }^{1}$, Marcus Vinícius de Castro Rocha ${ }^{2}$, Edson Luiz Lima da Silva ${ }^{3}$, Shaiene \\ Costa Moreno ${ }^{4}$, Sérgio Thode Filho ${ }^{5}$ \\ ${ }^{1}$ Professor at the Federal Institute of Education, Science and Technology of Rio de Janeiro - IFRJ, Campus Pinheiral, RJ, \\ Multidisciplinary Laboratory of Agro-Environmental Technology - LAMTAA. heider.franco@ifrj.edu.br \\ ${ }^{2}$ Agricultural Technician at the Federal Institute of Education, Science and Technology of Rio de Janeiro - IFRJ, Campus \\ Pinheiral, RJ \\ ${ }^{3}$ Laboratory assistant at the Federal Institute of Education, Science and Technology of Rio de Janeiro - IFRJ, Campus \\ Pinheiral, RJ \\ ${ }^{4}$ Professor at the Federal Institute of Education, Science and Technology of Rio de Janeiro - IFRJ, Campus Pinheiral, RJ \\ ${ }^{5}$ Professor at the Federal Institute of Education, Science and Technology of Rio de Janeiro - IFRJ - IFRJ, Campus Duque \\ de Caxias, RJ, Multidisciplinary Waste Management Laboratory - LMGR
}

\begin{abstract}
Soy is a product of agriculture that has a diversified use as food or raw material for derivatives such as oil and bran. There are studies evaluating the effect of residual vegetable oil on soil and other natural resources. However, environmental impact studies of refined soybean oil were not found in the literature. Thus, due to the large production volume of refined soybean oil, this work aims to investigate the response of earthworm escape, simulating the inadequate disposal of this residue in sandy and clayey soil. A completely randomized design with seven treatments consisting of doses of refined soybean oil added to the sandy and clayey soils was used: T1 - 1.0 mL; T2 - 10.0 mL; T3 - 15.0 mL; T4 - 20.0 mL; T5 - 25.0 mL; T6 - 30.0 mL and T7 - $100.0 \mathrm{~mL}$ in triplicate. The results show that for $15 \mathrm{~mL}$ and $20 \mathrm{~mL}$ doses, the refined soybean oil promoted a deleterious effect on the sandy and loamy soils, respectively, causing at least $60 \%$ of the earthworms to escape.
\end{abstract}

Keywords: Discard. Vegetable oil. Environmental impact. Eisenia fetida. 


\section{Introduction}

Soy is a product of agriculture that has diversified use, as well as food or raw material for derivatives such as oil and bran. Besides the grain is used in the production of, for example, chocolate, ready-made spices, sauces and pasta. Its use includes human and animal feeding, where soybean meal is used in feed composition (SANTOS et al., 2009). In addition to industrial, cosmetic, pharmaceutical, veterinary, paints and plastics, it also provides the destination for biodiesel production (APROSOJA, 2017).

The oil extracted from the grain represents $15 \%$ of the soybean production in grains, and is destined for production of cooking oil, margarine, vegetable fat, mayonnaise and others. The world production of vegetable oils grew around 400\% between 1974 and 2007, rising from 25.7 million to 123.1 million tons. Soybean oil world production rose from 6,476 thousand tons to 35,868 thousand tons, an increase of approximately $82 \%$. In the 2006/07 harvest, world consumption of soybean oil reached 35,641 thousand tons, with food use (35,153 thousand tons) being the largest production target, followed by industry use (2,488 thousand tons). In Brazil, soybean oil is the most consumed, reaching 3.2 million tons in $2006 / 07$ or $86 \%$ of the total consumed of vegetable oils (3.72 million tons) (NUNES, 2007).

In general, soybean oil is only marked when complying with the following physicochemical characteristics: specific weight $\left(25{ }^{\circ} \mathrm{C}\right)$ : 0.916-0.922 g.cm ${ }^{-3}$; Iodine index: $120-141 \mathrm{gI}_{2}, 100 \mathrm{~g}^{-1}$; saponification index: 180-200 mg KOH.g-1 ; unsaponifiable matter: $<1.0 \%$; acidity: $<0.3 \%$ oleic acid and peroxide index: $<10.0$ meq kg-1 (ANVISA, 1999).

There are studies evaluating the effect of residual oils, vegetables, oil, amongst others on soil and other natural resources (GONG et al. 2005a; 2005b; THODE-FILHO et al., 2017). However, environmental impact studies of pre-consumer refined soybean oil were not found in the literature since inadequate disposal in the environment may occur in its production, transport and/or storage.

The soil is a source of water and nutrients for plants and other organisms, also a buffering agent for changes in temperature and water flow between the atmosphere and groundwater. Likewise, it acts as a reservoir of nutrients and as habitat for organisms decomposers in cycling and availability of nutrients. Hence, pollution of the edaphic ecosystem can have important consequences for all life forms and the quality of food, water and atmosphere (WILD, 1993). This assertion corroborates the importance of conducting bioassays to ensure that contamination is known to compromise soil function.

Toxicity tests that aim to predict the potential impact of a xenobiotic (toxic agent) on environment (FLOHR et al., 2005) should be performed to analyze the toxic effects for a substance or mixed substances improperly discarded. For such, test organisms are used. They experience adverse effects when in contact with toxic substances. Amongst the adverse effects, one can include a range of from genetic alterations and immobility, up to deformities and mortality (MAGALHÃES; FERRÃO FILHO, 2008).

Earthworms are one of the organisms used in ecotoxicity testing, where the red-of-California or manure worm (Eisenia fetida) is the most common. This preference is due to its ability to convert organic waste little chemically broken into stabilized material. In addition, they have extensive playback capabilities and rapid growth. In this sense, these worms are an important link in terrestrial trophic web, providing resources for a wide variety of organisms, including birds, mammals, reptiles and amphibians. They represent a good alternative to achievement of 
ecotoxicological tests because they are simple to handle, easy to find as well as good indicators for the soil quality (ANDREA, 2010; CORREIA; MOREIRA, 2010; DITTBRENNER et al., 2011).

The contaminants in the soil can be adsorbed on the mineral particles, organic matter and soil solution and, therefore, the earthworms are exposed to the compounds through the ingestion of the soil (SPADOTTO et al., 2004; CORREIA; MOREIRA, 2010).

Thus, due to the large volume of production of refined soybean oil, this work aimed to investigate the earthworm evasion response, simulating the inadequate disposition of this residue in sandy and loamy soils.

\section{Material and methods}

\subsection{Materials}

The implantation and conduction of the tests took place in the Multidisciplinary Laboratory of Agro-Environmental Technology (LAMTAA) of Pinheiral Campus of the Federal Institute of Rio de Janeiro, located in the municipality of Pinheiral-RJ, geographical coordinates 22 $31^{\prime} 12.57^{\prime \prime} \mathrm{S}$ and $43^{\circ} 59^{\prime} 30.61^{\prime \prime} \mathrm{W}$.

We used one sample of tropical soil with sandy and loamy texture, collected between 0 and $20 \mathrm{~cm}$ depth (Table 1) in Pinheiral, RJ. Soils used in the tests were physico-chemically characterized according to the method recommended by the Brazilian Agricultural Research Company - EMBRAPA (1997) (Table 1).

\subsection{Methods}

\subsubsection{Earthworm escape test}

The avoidance test (ABNT NBR 17512-1, 2011) was performed for both types of soil using transparent plastic boxes $(28.8 \mathrm{~cm} \times 10.8 \mathrm{~cm} \times 4.2 \mathrm{~cm})$ with an approximate capacity of $500 \mathrm{~g}$ dry weight. The boxes were assembled with a strip of cardboard, placed transversally in the middle of the carton. Later, one half of the halves were filled with $250 \mathrm{~g}$ of control soil, without addition of soybean oil, and the other half filled with $250 \mathrm{~g}$ of soybean oil on soil.

Subsequently, the partition of the boxes was removed and added in the central position. Ten adult earthworms (Eisenia fetida sp) for each box were exposed at the same time to a control soil and to a soil containing the test substances. Test and control soil were placed in each test box as well as the earthworms that were presented to choose between the test soil and the control soil. The boxes should be closed and arranged in Type BOD germination chamber, with controlled temperature of $20 \pm 5{ }^{\circ} \mathrm{C}$ and photoperiod of 12 hours. The animals were not fed during the tests. After 48 hours, the percentage of earthworms present in each soil was evaluated.

For this test, a completely randomized design was used. Seven treatments consisted of doses of soybean oil which were added to the soils, namely: T1 - $1.0 \mathrm{ml}$; T2 - $10.0 \mathrm{ml}$; T3 - $15.0 \mathrm{ml}$; T4 $20.0 \mathrm{ml}$; T5 - $25.0 \mathrm{ml}$; T6 - $30.0 \mathrm{ml}$ and T7 - $100.0 \mathrm{ml}$. Each treatment was performed in triplicate.

The tests response for the two soil types containing soybean oil was calculated in terms of avoidance percentage per concentration. The avoidance percentage was calculated based on the following formula: $A=[(C-T) / N] \times 100$, where $C$ is the number of animals found in the control 
soil, $\mathrm{T}$ is the number of animals found on the test soil, and $\mathrm{N}$ the total number of animals used per treatment (for each concentration tested). A positive and indicative avoidance result is a negative attraction by the concentration of the active ingredient tested. According to the norm, $0 \%$ of escape indicates animal attraction to the chemical substance evaluated. On the other hand, a soil is considered toxic when more than $80 \%$ of exposed organisms prefer the control soil (leakage > 60\%) (ABNT, 2011).

\subsection{Statistical analysis}

We chose the Turkey test to analyze the statistical significance for dosages between the triplicates. The same test was used for significant differences between the triplicates results (COSTA NETO, 1977; MILLER; MILLER, 1993). All calculations and graphs presented in this work were performed by Assistat 7.7 (SILVA; AZEVEDO, 2016) and Microsoft Excel 2013.

\section{Results and discussion}

According to the results of Table 1, it is possible to identify that there is a physicochemical difference between the studied soils. The sandy soil presented a bases sum $\left(\mathrm{S}=\mathrm{Ca}^{2+}+\mathrm{Mg}^{2+}+\mathrm{K}^{+}+\right.$ $\left.\mathrm{Na}^{+}=6.52\right)$, as well as a high content of organic matter (C. org. $\left.=0.9\right)$. In relation to bases saturation percentage, this soil presented an excellent fertility condition and does not contain aluminum toxicity $\left(\mathrm{Al}^{3+}\right)$. The $\mathrm{pH}$ value found in the clay soil is considered acid which, along with the presence of $\mathrm{Al}^{3+}$, compromises the availability of other nutrients. It is also observed that the organic carbon content present in the sandy soil is three times lower than the loamy, representing an organic matter content of $1.6 \%$ and $0.52 \%$, respectively.

Table 1: Physical-chemical characterization of soils

\begin{tabular}{|c|c|c|c|c|c|c|c|c|c|c|c|c|}
\hline $\begin{array}{c}\text { Type of } \\
\text { soil }\end{array}$ & $\mathrm{pH} \mathrm{H}_{2} \mathrm{O}$ & $\mathrm{Ca}^{2+}$ & $\mathrm{Mg}^{2+}$ & $\mathbf{K}^{+}$ & $\begin{array}{c}\mathrm{Na}^{+} \\
\mathbf{c m o}\end{array}$ & & $\mathrm{Al}^{3+}$ & $\mathbf{H}^{+}+\mathbf{A l}^{3+}$ & $\mathbf{T}$ & $\begin{array}{c}P \\
m g ~ d^{-3}\end{array}$ & $\begin{array}{r}\mathrm{V} \\
\end{array}$ & C.org. \\
\hline Sandy & 7.5 & 5.8 & 0.64 & 0.05 & 0.03 & 6.52 & 0.0 & 1.20 & 7.67 & 320.80 & 85.00 & 0.90 \\
\hline Loamy & 5.2 & 1.57 & 0.39 & 0.01 & 0.03 & 2.00 & 0.3 & 1.98 & 3.98 & 3.00 & 50.00 & 0.30 \\
\hline
\end{tabular}

The community of earthworms present in a given location is dependent on soil characteristics (soil type, mineralogy, organic matter content, texture, structure, temperature, humidity and $\mathrm{pH}$ value), vegetation (species and cover) (precipitation, temperature, relative air humidity, wind), interaction with other soil organisms, as well as soil and local conditions (human and geological history) (BROWN; DOMÍNGUEZ, 2010).

Earthworms are considered excellent indicators of the quality of agroecosystems because they respond to different types of land use and management (Paoletti, 1999; Lavelle et al., 2006), being related to environmental conditions such as soil fertility and susceptibility to disturbance and habitat contamination (BROWN; DOMÍNGUEZ, 2010).

According to Technical Standard NBR 10.004 Solid waste - Classification (ABNT, 2004), the soy vegetable oil is classified as: Class II A, Not Hazardous - Not Inert.

In sandy soil, there is no leakage of earthworms, that is, avoidance of more than $60 \%$ in doses of soybean oil of less than $15 \mathrm{~mL} / 250 \mathrm{~g}$, but above this dosage the soil has become toxic to 
earthworms (Graph 1). A quadratic relation was observed between the soy vegetable oil dosage and the avoidance.

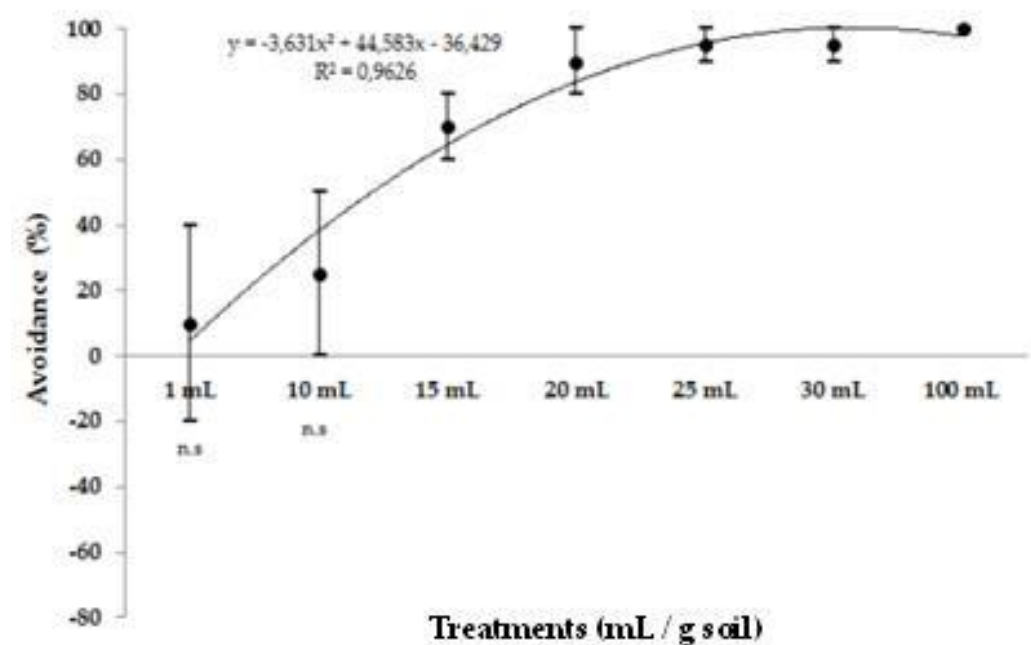

Graphic 1 - Eisenia fetida avoidance response contaminated with different soy vegetable oil dosages in sandy soil. Mean values and standard deviation bars, Tukey test, $\mathrm{p} \leq 0.05 ; \mathrm{n} . \mathrm{s} .=$ not significant.

In loamy soil, tolerance of earthworms was slightly higher. Dosages below $20 \mathrm{~mL} / 250 \mathrm{~g}$ did not cause leakage in more than $60 \%$ of the earthworms (Graph 2). A quadratic relationship between the dosage of soybean oil and the leakage in both soils was observed.

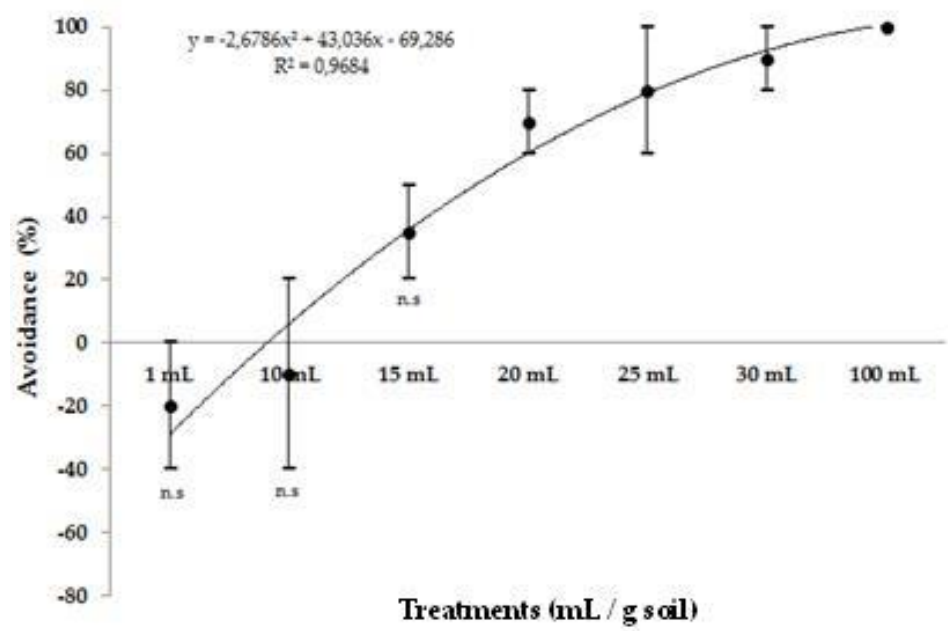

Graphic 2 - Eisenia fetida avoidance response contaminated with different soy vegetable oil dosages in loamy soil. Mean values and standard deviation bars, Tukey test, $\mathrm{p} \leq 0.05 ; \mathrm{n} . \mathrm{s} .=$ not significant.

The species used in this study are classified as epigeic (grouped by environment preference) and live in upper layers of the soil $(0-10 \mathrm{~cm})$ rich in organic matter (VAN GESTEL, 1992; SANTORUFO et al., 2012). However, the worm's skin is covered by a thin cuticle and produces enough mucus that facilitates the locomotion and protection of the skin. The mucus still protects the skin in contact with pollutants or toxic substances. The worm propels its previous segments, causing a wave that shifts back of its body. Concomitant to this, in the anterior region, the circular musculature contracts and the longitudinal muscles relax, causing their rings to become thinner 
and elongated and their bristles retained. In this way, the earthworm establishes a foothold in the ground and propels itself forward. Soils that have high humidity facilitate their displacement. The loamy soils accumulate more water in their particles, reason why the friction with their bodies is smaller, while guaranteeing gas exchange in respiration (BROWN et al., 2004; JAMES; BROWN, 2006).

Although the loamy soil used in the present study has low organic matter content, it is inferred that the earthworm tolerance in this soil was higher due to a greater locomotion capacity and soil mass exploration.

From the displacement and the ingestion of contaminated soil, the contact of the earthworms occurs with the pollutants that are disposed or applied to the soil and remain in it, either adsorbed on the surface of the colloids or available in the soil solution (VIJVER et al., 2003; CASTELLANOS; HERNANDEZ, 2007). Considering this acute worm-pollutant contact, they may compromise their displacement and they may escape, intoxicate, die, incorporate and even bioaccumulate these in their tissues (CURRY, 2004; SPADOTTO et al., 2004).

Wang et al. (2010) conducted an earthworm avoidance test with petroleum sludge and found that the limiting dose was $4.25 \mathrm{~g} / 250 \mathrm{~g}$ soil.

Thode-Filho et al. (2017) evaluated the earthworm leakage response after application of residual vegetable oil in sandy soil was $20 \mathrm{~mL} / 250 \mathrm{~g}$ and for the clay soil $26 \mathrm{~mL} / 250 \mathrm{~g}$, corroborating with the results of the present study with pre-consumption refined vegetable oil.

\section{Conclusion}

The results show that, for $15 \mathrm{~mL}$ and $20 \mathrm{~mL}$ doses, the refined soybean oil promoted a deleterious effect on the sandy and clayey soils, respectively, causing at least $60 \%$ of the earthworms to escape.

From these results, it is recommended that new bioassays with different organisms are made to reaffirm the deleterious potential of soybean oil on the environment.

\section{References}

ANDREA, M.M.D. O uso de minhocas como bioindicadores de contaminação de solos. Acta Zoológica Mexicana (nueva serie), n. 2, p. 95-107, 2010.

AGÊNCIA NACIONAL DE VIGILÂNCIA SANITÁRIA (Brasil). Resolução - RDC no 482, de 23 de Setembro de 1999. Regulamento Técnico para Fixação de Identidade e Qualidade de óleos e gorduras vegetais. Diário Oficial da República Federativa do Brasil, Brasília, DF, 11 mar.1999.

APROSOJA - Associação dos Produtores de Soja do Brasil. Uso da Soja. Disponível em: http://aprosojabrasil.com.br/2014/sobre-a-soja/uso-da-soja/. Acesso em: 07 de Set. 2017.

ASSOCIAÇÃO BRASILEIRA DE NORMAS TÉCNICAS. NBR ISO 17512-1. Qualidade do solo Ensaio de fuga para avaliar a qualidade de solos e efeitos de substâncias químicas no comportamento. Parte 1: Ensaio com minhocas (Eisenia fetida e Eisenia andrei). Rio de Janeiro: 2011.

BROWN, G.G., DOMÍNGUEZ, J. Uso das minhocas como bioindicadoras ambientais: princípios e práticas - o $3^{\circ}$ Encontro Latino Americano de Ecologia e Taxonomia de Oligoquetas (ELAETAO3). Acta Zoológica Mexicana, 26, Número especial 2: 1-18, 2010. 
BROWN, G.G., EDWARDS, C.A., BRUSSAARD, L. How earthworms affect plant growtt: burrowing into the mechanisms. In: EDWARDS, C. A. (Ed.). Earthworm ecology. Boca Raton: CRC Press, 2004. p. 13-49.

CASTELLANOS, L.R., HERNANDEZ, J.C.A. Earthworm biomarkers of pesticide contamination: Current status and perspectives. Journal of Pesticide Science. 32: 360-371, 2007.

COSTA NETO, P.L.O. Estatística. São Paulo: Edgard Blücher, 1977. 264p.

CORREIA, F.V., MOREIRA, J.C. Effects of glyphosate and 2,4-D on earthworms (Eisenia foetida) in laboratory tests, Bull. Environ. Contam. Toxicol., v. 85, p. 264-268, 2010.

CURRY, J. P. Factors affecting the abundance of earthworms in soils. 2nd Ed. Boca Raton: C. A. Edwards (Ed.), Earthworm ecology, CRC Press, 2004. Pp. 91-113.

DITTBRENNER, N., SCHMITT, H., CAPOWIEZ, Y., TRIEBSKORN, R. Sensitivity of Eisenia fetida in comparison to Aporrectodea caliginosa and Lumbricus terrestris after imidacloprid exposure. Body mass change and histopatology, J. Soil Sediments, v. 11, p. 1000-1010, 2011.

EMBRAPA - Empresa Brasileira de Pesquisa Agropecuária. Manual of methods of soil analysis. Rio de Janeiro: Embrapa-CNPS. 1997. 212p

FLOHR, L.; BRENTANO, D.M.; CARVALHO-PINTO, C.R.S.; MACHADO, V.G. \& MATIAS, W.G. Classificação de resíduos sólidos industriais com base em testes ecotoxicológicos utilizando Daphnia magna: Uma alternativa. Biotemas, 18:7-18, 2005.

LAVELLE, P., DECAËNS, T., AUBERT, M., BAROT, S., BLOUIN, M., BUREAU, F., MARGERIE, P., MORA, P., ROSSI, J.P. Soil invertebrates and ecosystem services. European Journal of Soil Biology, 42, Supplement 1: S3-S15, 2006.

MILLER, J.C., MILLER, J.N. Statistics for analytical chemistry. 3a ed. Chichester: Ellis Horwood. 233p., 1993.

NUNES, S.P. Produção e consumo de óleos vegetais. Departamento de Estudos Socio-econômicos Rurais. Boletim Eletrônico no 159 - Jun de 2007.

GONG, Z., ALEF, K., WILKE, B.M., LI, P. Dissolution and removal of PAHs from a contaminated soil using sunflower oil. Chemosphere, 58, 291 e 298, 2005a.

GONG, Z., WILKE, B.-M., ALEF, K., LI, P.. Influence of soil moisture on sunflower oil extraction of polycyclic aromatic hydrocarbons from a manufactured gas plant soil. Sci. Total Environ. 343, 51 e 59, $2005 b$.

JAMES, S.W., BROWN, G.G. Earthworm ecology and diversity in Brasil. In: MOREIRA, F. M. S.; SIQUEIRA, J. O.; BRUSSAARD, L. (Eds.). Soil Biodiversity in Amazonian and Other Brazilian Ecosystems. CABI Publishing: Wallingford, 2006. p. 56-116.

PAOLETTI, M.G. The role of earthworms for assessment of sustainability and as bioindicators. Agriculture, Ecosystems \& Environment, 74, 1-3: 137-155, 1999. 
SANTOS, A.D.F., TORRES, C.A.A., RENNÓ, F.P., DRUMOND, M.R.S., FREITAS JÚNIOR, J.E. Utilização de óleo de soja em rações para vacas leiteiras no período de transição: consumo, produção e composição do leite. Revista Brasileira de Zootecnia, 38(7), 1363-1371, 2009. https://dx.doi.org/10.1590/S1516-35982009000700028

SANTORUFO, L., VAN GESTEL, C.A., ROCCO, A., MAISTO, G. Soil invertebrates as bioindicators of urban soil quality. Environmental Pollution, v. 161, p. 57-63, 2012.

SILVA, F. de A.S., AZEVEDO, C.A.V. de. The Assistat Software Version 7.7 and its use in the analysis of experimental data. Afr. J. Agric. Res, v.11, n.39, p.3733-3740, 2016. DOI: 10.5897/AJAR2016.11522.

SPADOTTO, C.A., GOMES, M.A., LUCHINI, L.C., ANDREA, M. de. Monitoramento do risco ambiental de agrotóxicos: princípios e recomendações. Embrapa Meio Ambiente. Documentos 42, Jaguariúna, 2004.29p.

THODE-FILHO, S., PAIVA, J.L. de, FRANCO, H.A., PEREZ, D.V., MARQUES, M.R.C. de. Environmental impacts caused by residual vegetable oil In the soil-plant system. Ciência e Natura Journal, (2017). [no prelo]

VAN GESTEL, C.A.M. The influence of soil characteristics on the toxicity of chemicals for earthworms: a review, p. 44-54. In: GREIG-SMITH P. W., BECKER H., EDWARDS P. J.; HEIMBACH F. (Eds.). Ecotoxicology of earthworms. Intercept Press, Andover, 1992.

VIJVER, M. G., VINK, J.P.M., MIERMANS, C.J.H., VAN GESTEL, C.A.M. Oral sealing using glue: a new method to distinguish between intestinal and dermal uptake of metals in earthworms. Soil Biology and Biochemistry. 35: 125-132, 2003.

WANG, Shi-Jie et al. Ecotoxicity assessment of aged petroleum sludge using a suite of effectsbased end points in earthworm Eisenia fetida. Environmental monitoring and assessment. 2010; 169 (1-4): 417-428.

WILD, A. 1993. Soils and the environment: an introduction. Cambridge University Press. Cambridge. 